\title{
REVIEW
}

\section{Discrediting the Free Market}

\author{
Ian Ayres $\dagger$
}

The Progressive Assault on Laissez Faire: Robert Hale and the

First Law and Economics Movement. Barbara Fried. Harvard

University Press, 1998. Pp x, 338.

The free market has considerable appeal: freedom of contract maximizes liberty and competitive markets pay each input what it deserves-its marginal product. So the story goes. Barbara Fried, however, has written a masterful book that reminds us that these a priori defenses of the free market were long ago demolished. A small band of progressives-led by Robert Hale, an economist teaching at Columbia Law School-developed an especially piercing critique of standard justifications for libertarian market policies. Fried's book has rediscovered this critique and has made it available to modern readers.

Intellectual histories often raise two related questions concerning authorship. First, "Who is the author of particular ideas?" Fried is particularly sensitive to the possibility that she may have attributed to Hale the contributions of his predecessors and contemporaries. For example, Fried writes:

There is a perhaps irresistible temptation in writing on one person's work to exaggerate his singular contribution. Like a light shining on a polished surface, which creates the optical illusion that random scratches on the surface are arranged in concentric circles around it ... one is inevitably tempted

$\dagger$ William K. Townsend Professor of Law, Yale Law School. Jennifer Brown, Barbara Fried, Bob Gordon, and Brian Leiter all provided helpful comments. 
to cast one's subject as the source of ideas that swirl around and through him (pp 213-14).

I am not qualified to assess directly whether Fried has fairly represented Hale's specific contributions to the "Progressive Assault," but the book displays meticulous research, and Fried is careful to locate Hale's thought in the context not only of contemporary policy debates but also classical political economy. I instead worry that Fried's own views may be influencing her portrayal of Hale-that in excavating the gems from the past, she may have polished them beyond their original luster. This shading is a particular possibility because Fried seems so sympathetic to Hale's criticism of laissez faire. Fried, the intellectual historian, for the most part has kept herself off stage, preferring instead to report Hale's ideas faithfully. This narrative choice is especially lamentable because the few times when Fried, the theorist, does come forward and set out her own views, they are stunningly acute. ${ }^{2}$

Indeed, the quality of Fried's own analysis raises a second question about intellectual histories: "Why should we care about authorship?" We should certainly care about whether a particular argument is compelling, but it is far less clear that we should care about whether Hale was the true originator of the idea itself. Beyond the incentive effects that the "proper citation" norm gives for scholarly innovation, it is often unclear what the payoff of intellectual history should be. ${ }^{3}$ Indeed, it is unlikely that Hale himself would have written (or even valued reading) such a book, ${ }^{4}$ because it might have been too disconnected from the core realist questions of describing what the law is and what it should be ( $p$ 14). ${ }^{5}$ Fried explicitly responds to this concern:

1 This is in part because some of Fried's analysis turns on materials that Hale developed for his Columbia Law School "Legal Factors in Economic Society" course and other unpublished sources.

${ }^{2}$ See, for example, Fried's analysis of optimal taxation (pp 203-04) and reservation prices (p 134).

3 There are of course other potential presentist payoffs of intellectual history. Understanding in context what forces influenced Hale's thought may help us see ways that our current thinking has been artificially constrained. I also embrace an "option value" defense of intellectual history. Even if the past knowledge is not currently useful, it may be beneficial to preserve it-just in case.

1 Perhaps Hale did engage in intellectual biography. A small shortcoming of the book is that it does not include a bibliography of Hale's work.

s See also Fried (p 13), quoting Felix Cohen, Transcendental Nonsense and the Functional Approach, 35 Colum L Rev 809, 824 (1935) ("Fundamentally there are only two significant questions in the field of law. One is, How do courts actually decide cases of a given kind?' The other is, 'How ought they to decide cases of a given kind?'”). 
The book is primarily a work of intellectual history-an attempt to excavate and restore in its historical context an elaborate and (in its time) seditious argument about the nature of law and legal rights. At the same time, the excavation was motivated in part by the conviction that Hale's argument retains force in the political and intellectual debates of our own day, particularly those concerning the proper role of government in economic redistribution ( $\mathrm{p} 28$ ).

It may have been more useful, however, for Fried to use Hale to confront current libertarian thinking - say, to interrogate directly Robert Nozick's or Richard Epstein's contemporary arguments. ${ }^{6}$

Indeed, the thesis of this review is that Hale -in a sustained argument running through several publications-successfully demolished several standard a priori libertarian arguments, many of which still appear in contemporary debates. However, his affirmative policy agenda was much less successful. Fried shows that Hale's own affirmative redistribution agenda could not ultimately be justified by notions of Lockean sacrifice. Moreover, much of Hale's constitutional analysis is innocent of even rudimentary forms of textualism or originalism. Nonetheless, Hale should rightfully be remembered for discrediting simplistic laissez faire justifications. Hale showed that government regulations do not, as a conceptual matter, interject coercion into our world but rather (re-)distribute the coercion that unavoidably inheres in any system of private property.

This review is divided into four sections. The first assesses Hale's central contributions-his most salient criticisms of laissez faire as well as his affirmative Lockean proposals to extract producers' inframarginal rents. The second section argues that Hale at times did not follow his professed Lockean convictions to their natural conclusions. Section three criticizes Hale's applied policy agenda, noting particularly his inattention to traditional tools of constitutional construction. The last section assesses the suggestion in Fried's subtitle that Hale was part of "the first law and economics movement."

- Fried herself has done this in separate writing. See, for example, Barbara Fried, Wilt Chamberlain Revisited: Nozick's "Justice in Transfer" and the Problem of Market-Based Distribution, 24 Phil \& Pub Aff 226, 227 (1995) (arguing that the libertarian concept of "justice in transfer" does not establish the justice of market-based distributions). 


\section{Central Halean INSightS}

\section{Freedom is merely privilege extended unless enjoyed by one and all. ${ }^{7}$}

Hale's analysis of liberty and its opposite, coercion, form a central pillar of his thinking. At the beginning of the century (and continuing to this day) many judges and scholars-including progressives-believed that government regulations were necessarily coercive restrictions of private liberty. ${ }^{8}$ Progressives argued that certain redistributive restrictions on liberty were nonetheless justified because they furthered the public good. But Hale, following Hobhouse and Hohfeld, argued instead that, as a conceptual matter, the total amount of legal freedoms must remain constant across different possible regimes (pp 51-54). Property rights impose (through the agency of the state) correlative restraints on nonowners. Expanding one person's freedom of choice necessarily restricts other people's ability to choose: if the law gives me the right to my body, it necessarily denies others this right. Liberty, in Fried's phrasing, is an "empty idea," because it is impossible for law to maximize freedom from interference with choice ( $p$ 52, chs 3-4). The formal and necessary conservation of total freedom suggests that the function of law is instead to distribute a fixed quantum of formal liberty. The implication of Hale's analysis is that in any legal system that distributes rights, the notion of true laissez faire-no government interference with individual rights-is not even a logical possibility ( $p 21$ ). As we will see, while Hale rejected as empty the concept of "negative" libertythat is, liberty from government interference-he, like other progressives, did embrace the possibility that law could further an egalitarian notion of "positive" liberty that "measure[s] the individual's power to effect his or her desires" (p 37). ${ }^{9}$

Hale adumbrated this startling distributive view of negative liberty by developing a sophisticated conception of what should constitute coercion. As with liberty, Hale argued that government should be seen as a distributor of legal coercion. Fried writes: "[W] to curb the use of certain private bargaining power, it did not in-

\footnotetext{
7 Billy Bragg, The Internationale, on The Internationale track 1 (Wea/Elektra Entertainment 1990).

${ }^{8}$ "Hale argued that traditional liberal thought had erroneously assumed that the government was the source of all legal coercion" ( $p$ 17).

${ }^{9}$ See also Robert L. Hale, Freedom Through Law (Columbia 1952) and T.H. Green, Liberal Legislation and Freedom of Contract, in John R. Rodman, ed, The Political Theory of T.H. Green 43, 51-52 (Appleton-Century-Crofts 1964).
} 
ject coercion for the first time into those relations; it merely changed the relative distribution of coercive power" ( $p 18$ ).

For Hale, all contracts were as a conceptual matter mutually coerced: "[E]ach party to [a] contract, by the threat to call on the government to enforce his power over the liberty of the other, imposes the terms of the contract on the other" (pp 55-56). ${ }^{10}$ Therefore, government restrictions on freedom of contract cannot be rejected merely because the government's action coerces one side or other of the agreement. Fried explains:

[Voluntary market exchanges are] in fact coerced by the common-law right of property owners and would-be laborers to withhold their property and labor, respectively, except on such terms of exchange as they demanded. That state of affairs meant that in intervening in private contracts to limit one side's right to dictate the terms of exchange, the government was indeed constraining that side's liberty, as laissez-faire proponents had argued. But it was simultaneously enlarging the sphere of choices, and hence liberty, of the other side ( $\mathrm{p} 46)$.

For Hale, government is the source of all legal coercion because of its ineluctable role in defining property rights. ${ }^{11}$

A particularly important aspect of Hale's contribution to coercion theory concerns his expansion of what constitutes coercion. Following Holmes, ${ }^{12}$ Hale rejected the notion that the term should only apply to instances where the coerced party lacks volitionthat is, the ability to make a choice. ${ }^{13}$ For example, in discussing the poverty of the pure volitional definition of coercion, Karl Rodbertus observed that "although the contract of labourer and employer has taken the place of slavery, the contract is only formally and not actually free, and Hunger makes a good substitute for the

${ }^{10}$ Quoting Robert L. Hale, Law Making by Unofficial Minorities, 20 Colum L Rev 451, 452 (1920).

" "Hale, by redefining the market as a system of mutual coercion, hoped to show that the ability to extract any price for one's goods or services depended upon the legal right to withhold them from others" ( $p 83$ ). Of course, absent property rights some property would not exist, but Hale believed that a large number of property regimes could still give adequate incentives to produce property.

${ }^{12}$ See Holmes's discussion of duress in Union Pacific Railroad Co v Public Service Commission of Missouri, 248 US 67, 70 (1918) (contending that "the fact that a choice was made according to interest does not exclude duress").

13 "The notion lingers on that coercion necessarily implies that the party to whom it is applied has no volition, as does the converse notion that where he has volition, or the ability to make a choice, there is no coercion or duress.' The assumption was simply wrong, Hale argued at length" (p 48), quoting Robert L. Hale, Bargaining, Duress, and Economic Liberty, 43 Colum L Rev 603, 616 (1943). 
whip" ( $p$ 47) ${ }^{14}$ Hale, however, insisted that any pejorative use of the term rest on some independent notion of what constitutes an illegitimate threat. As Fried describes Hale's position: "[F]inding an offer coercive is always parasitic on a prior, implicit determination either that the coerced party had a baseline entitlement to be free of such pressure or that the coercer had a baseline duty not to impose it" (p 59).

The recognition of this "baseline" problem is probably Hale's most lasting acknowledged contribution to contemporary legal scholarship - at least judging by continuing citations. ${ }^{15}$ Of course, this broader conception of coercion raises an important question: What are appropriate morally acceptable baselines for threatening not to contract?

Hale's response to the baseline problem is a form of egalitarianism constrained by utilitarian concerns about retaining sufficient incentives for productivity as well as Lockean notions of moral entitlement to property for which individuals have sacrificed. For example, the egalitarian/utilitarian strain in Hale's thinking can be seen in his "tentative," proto-Rawlsian view that property rights should be distributed

so as to maximize the aggregate real (positive) freedom enjoyed by society as a whole. The most likely means to that end ... was to increase the options available to the least well-off people in society, subject only to preserving adequate incentives for the richer members of society to be productive (p 46).

Just as Hale distinguished between positive and negative forms of liberty, he juxtaposed two different uses of "coercion"the traditional, "empty" definition that was related to his criticism of negative liberty, and the normative baseline definition that was related to his notion of positive liberty. Laws that fail to maximize the constrained egalitarian sense of positive liberty were coercive for Hale in the pejorative sense. As the foregoing quotation shows, the utilitarian notion of preserving adequate incentives exerted a strong pull on Hale, but Hale also strongly believed in an expansive notion of Lockean desert, which

14 Quoting Eugen V. Böhm-Bawerk, Capital and Interest: A Critical History of Economical Theory 332 (Macmillan 1890) (William Smart, trans), quoting Karl Rodbertus, Zur beleuchtung der socialen frage (Puttkammer \& Muhlbrecht 1875).

${ }^{15}$ A Westlaw search, for example, uncovered more than two hundred citations to Robert L. Hale, Coercion and Distribution in a Supposedly Non-Coercive State, 38 Pol Sci Q 470 (1923), and Robert L. Hale, Bargaining, Duress, and Economic Liberty, 43 Colum L Rev 603 (1943). 
held that private property rights should be commensurate with "the sacrifice actually incurred" (p 111). In other words, "Lockean theory (taken seriously) suggested that sellers were entitled only to that portion that compensated them for the cost of supplying the goods or services" ( $p$ 74).

While Locke's original theory turned on the labor sacrifice of a particular owner, the progressive "rent theorists" acknowledged other sacrifices, including the willingness of owners to forego present consumption for deferred consumption (which justified the payment of interest) (pp 118-19). For rent theorists like Hale, any returns to capital, labor, or land beyond what was a reasonable compensation for sacrifice actually incurred could be expropriated by government and redistributed on an egalitarian basis. Identifying Hale as a Lockean "rent theorist"-a term that Fried coined-is probably the book's most original contribution as an intellectual history. Fried persuasively shows that the redistributive policies of Hale and other progressives of his time were implicitly based on this expanded notion of Lockean sacrifice. Rent theory connects the disparate strands of progressive redistributive theory of the period and shows its ties to both past political economy and the modern "marginalist" revolution in economics.

Hale's notion of Lockean sacrifice undergirded not only his theory of what constitutes just factor prices (wages, interest, etc.), but also provided a normative baseline for delineating the pejorative contours of coercion in bilateral exchange. Thus, Hale believed that the unreasonableness of the terms (given the level of sacrifice), not compulsion, made an agreement "coercive" in the pejorative sense. Progressives repeatedly analogized to Jacob's unfair bargain with Esau: "When Jacob made his tired and hungry brother Esau sell his birthright to get some of the pottage that stood steaming and savory before him, he charged what the market could bear, but he did a shabby thing" ( $p$ 62). ${ }^{16}$ Jacob's meager sacrifice of pottage was in no way commensurate with his return and was thus unjustifiable to a Lockean like Hale.

Hale argued that "existing property arrangements that laissez-faire advocates sought to protect were not deducible from, and in some instances wholly irreconcilable with, Lockean premises" (p 73). ${ }^{17}$ In particular, for Hale the emerging "marginalist" eco-

\footnotetext{
${ }^{16}$ Quoting Walter Rauschenbusch, Christianizing the Social Order 233 (Macmillan 1912). Hale himself analogized to Jacob and Esau in arguing that markets could be as coercive as threats of physical force (p 57). The story itself appears at Gen 25:29-34.

${ }^{17}$ Fried notes that "laws of inheritence, land grants, and government grants of monopoly privilege" ( $p$ 19) were particularly pernicious to Lockean principles. John Stuart Mill added that " $[t]$ he laws of property have never yet conformed to the principles on which the
} 
nomic analysis did not provide a moral justification for laissezfaire policies. The marginalist revolution in economics showed that in a competitive market, "the price of each factor [of production] is determined by its contribution to value for the marginal purchaser (its so-called 'marginal productivity')" (p 126). ${ }^{18}$ Laissez-faire champion John Bates Clark eagerly gave a normative spin to this result, arguing that "the market automatically distributes income to factors in accordance with the ordinary (Lockean) intuition of justice: 'to each what he creates'" (p 24). ${ }^{19}$

The response of Hale and other progressives to the marginalists' defense of laissez faire was twofold. First, Hale criticized Clark's marginalist analysis as inconsistent with any Lockean notion of sacrifice:

The "marginal product," Hale argued, formally measured the value to the purchaser of a given input, not the cost to the supplier of providing it. In fact, Clark's marginal productivity theory contained no theory of costs at all. As Hale remarked, "the basis of distribution on this theory has shifted from the earlier basis of 'sacrifice' to that of 'imputed productivity,' a basis which Clark expressly approves as 'ethical,' but without any discussion of the grounds" ( $p$ 133). ${ }^{20}$

For a Lockean, giving "to each what he creates" is not a defensible distributional criterion. For example, applying Clark's theory to the story of Esau's bargain might suggest that Jacob deserved to gain a birthright if the marginal product of his sacrifice was sustaining Esau's life. ${ }^{21}$ However, justifying this high

justification of private property rests" (p 90). John Stuart Mill, in Principles of Political Economy bk II, ch I, \& 3 (Longmans, Green 1929), was the first to argue that existing property rights are not deducible from Lockean principles.

${ }^{18}$ Fried somewhat surprisingly claims that " $[\mathrm{b}] \mathrm{y}$ the 1890 s, marginal analysis had established complete dominance in economic analysis" ( $p$ 127). This assertion creates an interesting tension with Robert Lande's analysis of the legislative intent behind the Sherman Antitrust Act, also passed in 1890. Robert H. Lande, Wealth Transfers as the Original and Primary Concern of Antitrust: The Efficiency Interpretation Challenged, 34 Hastings L J 65, 88 (1982) (explaining that "no evidence has ever been found to suggest that any legislator understood that monopoly pricing causes allocative inefficiency").

${ }^{19}$ Quoting J.B. Clark, The Distribution of Wealth: A Theory of Wages, Interest, and Profits 9 (Macmillan 1899). Fried argues that "Clark's particular brand of naive apologetics was a source of embarrassment for most mainstream economists" ( $p$ 132), but apparently this embarrassment was not sufficient to keep the American economies profession from naming its most prestigious prize-awarded every two years to the most distinguished American economist under forty-after one John Bates Clark.

${ }^{20}$ Quoting Robert L. Hale, Economic Theory and the Statesman, in Rexford Guy Tugwell, ed, The Trend of Economics 191, 198 (Knopf 1924).

${ }^{21}$ Other readings are possible. For example, if Esau's capacity to assess his situation (and hence consent) was diminished by his hunger, he may (unbeknownst to himself) have been able to survive without the food. In that case, the marginal product would have been 
"price" in terms of Jacob's productivity (sustaining Esau's life) instead of in terms of Jacob's sacrifice (foregoing pottage) was, for the Lockean Hale, "shabby."

Second, rent theorists focused on the possibility of supracompetitive returns accruing not just to participants in uncompetitive markets, but also to "inframarginal" producers in competitive markets. Even though price tends toward marginal cost in a competitive equilibrium, producers could earn substantial profits on inframarginal units of production. Rent theorists were preoccupied with the "unearned surplus" going to inframarginal factors of production:

[I]nframarginal and monopoly rents . . could, in theory, accrue to any factor of production, labor as well as land and other forms of capital. ... [L]abor had no more right to the surplus value that it generated over its own sacrifice than did capital. . . . If anyone had a right to surplus value, the progressives argued, it was not any particular factor, but rather society at large ( $\mathrm{p} 27$ ).

So far so good. I agree with Fried that Hale's primary contributions were to discredit any a priori belief in laissez faire. Hale's analysis demolished as an analytic matter the old notion that the free market maximized "negative" liberty by minimizing government interference ( $p$ 46). Likewise, Hale's conclusion that coercion is an inevitable byproduct of private property is compelling because the government redistributes, rather than interjects, coercive power when it regulates. Finally, the theoretical possibility that free market competition could drive factor prices (such as wages and interest rates) to equal marginal productivity does not-contrary to Clark's naïve arguments-provide an adequate ground for accepting the distributive effects of laissez-faire regimes.

In the end, Hale conceded that as a pragmatic matter laissezfaire policies may, by and large, still be appropriate:

Utilitarian considerations might still counsel against widespread intervention in market-based distribution, if the government could not deprive inframarginal producers of rents without disrupting the return to marginal producers as well. ... "In orthodox economics, the only intelligent excuse for the profit system is, not that it results in a 'fair' distribution of wealth-for no sane modern economist could maintain that absurd thesis-but rather that profits furnish an incen- 
tive necessary to get the work of the world accomplished" (p 114). ${ }^{22}$

After Hale, laissez-faire defenders needed to descend from lofty a priori arguments to messy empirical issues concerning the likely real-world response to particular market interventions.

\section{THE IMPERFECT LOCKEAN}

While Hale used Lockean desert theory to criticize Clark and other marginalists, Hale's own distributional theory departed from Lockean sacrifice principles in two ways. First, Hale settled for using "reservation prices," a weak measure of Lockean sacrifice. Additionally, Hale (and other progressives) showed insufficient interest in extracting the "unearned surplus" of consumers.

\section{A. Can Reservation Prices Measure Lockean Sacrifice?}

Hale believed that in distributing wealth the law should presumptively foster equality. However, this presumption was constrained both by the Lockean notion of desert and by the caveat that certain inequalities "must be tolerated to the extent that they functioned as a necessary spur to productivity" (p 69). Of course, these two constraints might not be identical. Hale, however, "argued at length in developing his rent-theory version of distributive justice [that] both objectives would be satisfied if individuals were allowed to benefit from any disproportionate coercive power that they possessed only to the extent of a just reward for the sacrifice their efforts entailed" ( $p$ 69). This formulation suggests that focusing on Lockean "sacrifice" will also give sufficient incentives to produce.

But in practice most progressives took the opposite tack by proposing regimes that focused on providing productivity incentives and then arguing that doing so would be coincident with Lockean morality. For example, in analyzing just wages, they "generally accepted that the minimum price that workers demanded for forgoing leisure should be equated with their relevant sacrifice for moral (Lockean) purposes" (p 136).

Hale had criticized Clark's "marginal productivity" analysis for having no theory of sacrifice, but, somewhat startlingly, Hale had no workable theory of sacrifice himself:

[The question of] a normative theory of what ought to count as cost . . . received surprisingly little attention. Most com-

${ }^{2}$ Quoting James C. Bonbright, 1 The Valuation of Property 409 (McGraw-Hill 1937). 
mentators simply assumed without discussion that "costs" for these purposes ought to be equated with incentive-based costs. That is to say, costs should be measured by the minimal price (the so-called "reservation price") that a would-be worker or saver would demand for forgoing leisure or present consumption ( $\mathrm{p} 134){ }^{23}$

Establishing laws that give individuals their "reservation price" is well-tailored to assure the productivity constraint. Such laws ensure at least the minimum return that an individual demands in order not to threaten credibly to withhold her input. ${ }^{24}$ But "reservation prices" are poor proxies for Lockean desert.

In an insightful set of pages, Fried levels three devastating criticisms against the proposition "to each her reservation price," showing that these measures may diverge substantially from any reasonable sacrificial theory of desert. First, updating the views of Herbert Davenport, Fried shows why reservation prices of workers are distinct from reasonable measures of sacrifice:

The price that a worker demands for forgoing a marginal hour of leisure, Davenport argued, measures only the relative preferences such worker has for leisure and money (what modern economists would describe as the "marginal rate of substitution" between the two goods). It says nothing about the absolute pleasure or pain associated with either choice. For the artist who "may have enjoyed every hour of his productive activity, and may leave it ... [only] at the call of some greater alternative pleasure awaiting him," the choice may be "between pleasant productive activity, on the one hand, and pleasant leisure on the other; [so that] even at the margin . . . there is no necessity of pain cost." Moreover, for those workers for whom work may be unpleasant, one cannot deduce the degree of unpleasantness from the price that they demand for enduring it, as that price reflects only the relative values that they place on avoiding work and obtaining money ( $p$ 135). ${ }^{25}$

\footnotetext{
${ }^{23}$ Indeed, it is not clear that Locke's own labor theory was based on sacrifice. See Lawrence C. Becker, Property Rights: Philosophic Foundations 32 (Routledge \& Kegan Paul 1977) ("The root idea of the labor theory is that people are entitled to hold, as property, whatever they produce by their own initiative, intelligence, and industry.").

${ }^{24}$ See Jennifer G. Brown and Ian Ayres, Economic Rationales for Mediation, $80 \mathrm{Va} \mathrm{L}$ Rev 323, 331 (1994) (discussing the relationship between reservation prices, threat points, and BATNAs (best alternatives to negotiated agreements)).

${ }^{25}$ Quoting Herbert Davenport, Value and Distribution: $A$ Critical and Constructive Study 82 (Chicago 1908).
} 
Davenport's point was not just that reservation prices are poor proxies for Lockean sacrifice, but that they are likely to overstate systematically the supposed sacrifice of the rich: "Accepting the general (post-Edgeworthian) view that the utility of money declines with increasing wealth, Davenport argued that the relative reservation prices placed on work were therefore likely systematically to understate the relative pain that work entailed for the poor as compared with the rich" ( $p$ 135).

Second, Fried shows why short-run reservation prices may diverge substantially from notions of Lockean sacrifice. As Alfred Marshall noted, "A great part of a worker's earnings are of the nature of a deferred return to the trouble and expense of preparing him for his work" ( $p$ 135). ${ }^{26}$ But because these prior sacrifices of education and preparation are already sunk costs, they will not influence "the price actually demanded at any time for forgoing leisure (that is, ... . the short-run supply curve)" (p 135). The minimum price that a skilled craftsperson demands in exchange for her work during an unexpected economic downturn may not have much to do with the "true" sacrifice entailed in becoming skilled in the first place.

Third, Fried points out that any concept of sacrifice must at bottom be parasitic on some belief that an individual initially owns the item being sacrificed. Ownership is key, for the simple reason that one cannot sacrifice something that one does not own. As Fried puts it:

[T] he notion that people are entitled to what they earn by the sacrifice entailed in their labor rests on the premise that people "own" the right not to work at all. One need not go so far as to advocate slavery to question that premise. One could, for example, believe that there exists a moral obligation on every citizen to contribute some amount of labor to society in accordance with her ability, in exchange for support from the state determined solely by her needs ( $p 135$ ).

It is somewhat surprising that Hale did not see that reservation prices might themselves be a function of the law.

Together these three criticisms suggest that reservation prices are poor proxies for Lockean desert. While Hale was right to criticize theories of sacrifice based on marginal productivity, equating "marginal cost" or reservation price with sacrifice may not provide a firmer Lockean foundation for distributing social wealth.

${ }^{26}$ Quoting Alfred Marshall, Principles of Economics 831 (Macmillan 8th ed 1937). 


\section{B. Expropriating Consumer Surplus}

Accepting for the moment that the use of reservation prices (or threat points) as proxies for Lockean sacrifice is viable, Hale and other progressives were still surprisingly unwilling to go after an incredibly important source of "unearned surplus"-consumer surplus. Fried repeatedly describes Hale as an analytic extremist who had an "inclination to push [a] point to its logical extreme" ( $p$ 19). But in at least one respect Hale and other progressives were willing to leave a lot of unearned dollars untouched. The "law of three rents" maintained that in an unregulated market, labor, land, or capital could each earn returns on inframarginal production that were disproportionate to their sacrificethat is, far exceeding their reservation price. Progressive rent theorists were "formally evenhanded as between labor, land, and other forms of capital" ( $p$ 27)-the unearned surplus of any factor was ripe for government expropriation..$^{27}$ But pushed to its logical extreme, rent theory should have taken aim at a fourth "rent," the unearned surplus accruing to consumers. If the Lockean theory of moral desert only justifies "ownership of that portion of exchange value that represented a fair price for the sacrifice actually incurred," then consumers should not gain some right that they greatly value for a mere pittance ( $p$ 111). In other words, rent theorists should be as concerned with consumer underpayment as seller overcharging. To put it most provocatively, Jacob may have done a shabby thing to charge Esau a great deal for saving his life, but, by the same argument, Esau would be doing a shabby thing if he had to sacrifice only a small amount for such a benefit.

To be sure, neither Fried nor Hale are blind to this argument. For example, in considering optimal public utility regulations, progressives debated the merits of either (a) setting prices based on the costs of the specific utility or (b) setting prices "based on the costs to the high-cost producers ... and [ ] expropriat[ing] the surplus paid to low-cost producers by an excess profits tax" (p 196):

Either solution ... would limit the utilities roughly to a fair return on their actual investment. But the two solutions had quite different distributive implications. A cost rate base transferred any surplus value generated by the exchange to consumers, in the form of lower rates; an excess profits tax

${ }^{27}$ The "law of three rents" was developed by Sidney Webb (p 27) and embraced by the Fabian rent theorists ( $p$ 145). 
transferred it to the government. That most progressives, including Hale, saw the two solutions as morally interchangeable underscores their belief that the core injustice to be corrected by regulation was not exorbitant charges but exorbitant profits ( $\mathrm{p} 196$ ).

Hale, however, did ultimately prefer the high-price-cumexcess-profits-tax alternative and explicitly defended the higher prices to consumers by arguing that "the appropriation would take away "nothing which equitably belongs either" to the buyer or the seller"' (p 196). ${ }^{28}$

But at other times progressives were reluctant to extract unearned surplus from either consumers or workers. Hale at least partially recognized this inconsistency with his more general Lockean morals and attempted a limited defense. In an illuminating passage, Fried writes:

[B]y altering the exchange value of goods or services, the government did not expropriate surplus value; it merely transferred it from one side of the transaction to the other. If, as rent theorists argued, value in excess of cost was a social and not an individual product, why should the government intervene merely to reallocate the surplus from one undeserving party to another, rather than to appropriate it for public use? Where (as in public utilities rate regulation) the beneficiaries were consumers at large, the transfer might be defended as reasonably approximating the results that would be obtained by the more cumbersome route of taxing the utilities' gain and then redistributing the proceeds to the community. ... . To the extent that the community would have redistributed the proceeds of taxation to the neediest members of society, in which group the lowest-paid laborers were disproportionately represented, Hale suggested, one could defend the result as approximating what a system of pure rent-theory taxation followed by socialist welfarist redistributive transfers, would have accomplished (pp 151-52).

Hale thus suggested that one could allow consumers or workers to retain unearned surplus, if they would have regained such money anyway from "socialist welfarist redistributive transfers" under a purer Lockean system of tax (unearned surplus) and spend (redistribute). Of course, to test whether a particular group

${ }^{2}$ Quoting Robert L. Hale, Utility Regulation in Light of the Hope Natural Gas Case, 44 Colum L Rev 488, 527 (1944), quoting Dayton-Goose Creek Railway Co v United States, 263 US 456,484 (1923). 
would have regained the resources anyway, one needs a theory for how public funds should be allocated. Rent theory determines the amount of resources that are available for public redistribution but not how those funds should be redistributed ( $p 299$ n 251). On this point, Hale (or at least Hale as we know him through Fried) did not have much to say beyond generalized notions of promoting equality in wealth.

Still, Hale's rationales for not invading consumer (or worker) surplus are not completely satisfying. While Hale repeatedly analyzed Jacob's bargain with Esau (or the analogous negotiation with a drowning man) as a motivating case, he did not assess the extent to which Esau had a Lockean right to his unearned surplus. The drowning or starving man receives a great benefit in continued life, but Hale seems to think that it is just for him to sacrifice a very small price for this great benefit. How does this comport with Lockean desert?

Hale could reply that society under a mandated low-price regime would merely be letting Esau retain what society would have given back to him under a purer Lockean system. But why do we think that society would give back to Esau all the perquisites of being a first-born son? Hale might reasonably argue that a redistributive policy would have an insurance component that would insure that Esau was not left destitute after yielding his consumer surplus from this lifesaving bargain. Even so, an egalitarian insurance program would not ensure wealth acquisition far exceeding that of others in society. Egalitarian redistribution would instead tend to equalize wealth in society (or at least within Isaac's family). The general point is that there is no compelling reason to think that consumers (or workers) are the neediest or most worthy recipients of resources that from a Lockean perspective should be socially available. The purer Lockean system would force each side to the transaction to pay his or her reservation price. Under this system, all of the unearned producer and consumer surplus would revert to the state.

The possibility of inframarginal producers is central to rent theory (because it allows for low-cost producers to earn rents even in a competitive market). But Hale overlooks the Lockean implications of inframarginal consumers-that is, consumers who would have been willing to pay much more than the equilibrium price for the product. The negative slope of demand curves suggests that at least some consumers value traded goods at levels substantially greater than the equilibrium price. For example, even though the marginal consumer may be willing to pay only $\$ 30$ to see Michael Jordan play, I am acquainted with some in- 
framarginal consumers who would be willing to pay, if need be, much, much more. In the case of electrical utilities, it is plausible for Hale to argue that the "unearned surplus" taxed away from consumers by the state would subsequently return to them as an egalitarian redistribution. This is true, because as a first approximation we might believe that the consumers' individual surpluses from having the convenience of electricity are roughly the same. But there are many other goods where "inframarginal" consumers earn far more than marginal consumers. It is implausible to argue that an egalitarian regime would want to tax consumer surplus and then redistribute back widely varying amounts to individual consumers. If consumer surplus is really "unearned," there is no reason why-after the state expropriates consumer surplus-the marginal consumer of Kathleen Battle CDs, for example, should receive virtually nothing back from society while the true enthusiast would be entitled to thousands of dollars of redistributed income.

In his most Lockean moments, Hale was willing to allow a high consumer price and then tax away the excess profits, but he seemed unconcerned with charging different prices to different consumers (p 196) ${ }^{29}$ A pure Lockean system would ask each consumer to pay her reservation price for each unit of consumption. While Hale might have responded that such an idealized system is unachievable in the real world, we could come much closer to this ideal than Hale seemed to contemplate. A dedicated Lockean would want government to facilitate price discrimination by producers-in order to extract as much of the inframarginal consumers' unearned surplus as possible-and then tax away the producers' excess profits. An inventive Lockean could dream up several programs to allow manufacturers to charge consumers different prices. Besides repealing the Robinson-Patman Act, ${ }^{30}$ government might prohibit resale of products to stop arbitrage from low-price to high-price consumers. Hale, however, disliked price

\footnotetext{
${ }^{29}$ In a less Lockean moment, Hale merely strived for lower consumer prices:

Of the various means available for appropriating unearned incomes, the most obvious one was to alter the exchange value of goods and services to eliminate the surplus value. That goal could be accomplished either by altering the background conditions to exchange in order to equalize the bargaining positions of the parties, or by setting the exchange price to mimic what the market price would have been had the parties faced each other with equal bargaining power ( $p$ 150).
}

But contrary to the opening assertion, these strategies did not appropriate unearned incomes, but merely redistributed them from producers to consumers.

so 15 USC $\$ 13$ (1994) (prohibiting sellers from discriminating in price between buyers when doing so adversely affects competition). 
discrimination without ever confronting its appealing Lockean properties (pp 196-97). ${ }^{31}$.

Fried insightfully notes the parallels between Hale's brand of rent theory and so-called Ramsey (or optimal) taxation:

In order to minimize the efficiency loss from tax-induced distortions in people's behavior, a Ramsey tax sets tax rates on different commodities inversely proportional to the elasticity of demand. That is to say, the less price-sensitive (or elastic) the demand for a good, the higher the rate at which it is taxed. The now-familiar efficiency justification for this scheme is apparent: the less price-sensitive one's desire is for a given good, the less likely one is to be deterred from purchasing it if the price is raised by a tax. Thus, ideally, the effect of the tax is to reduce consumer surplus from a given purchase, without deterring the purchase entirely (pp 203-04).

Fried sees that "a rent-theory tax is, in effect, a Ramsey tax placed on producer (worker's or saver's) surplus rather than on consumer surplus" (p 204). But a true Lockean would want to combine both a Ramsey and a rent-theory tax in order to extract for public purposes both the producer and consumer surplus. The theory of Ramsey taxation and the foregoing discussion of government's role in facilitating price discrimination suggest that regulation capturing both surpluses could be implemented. ${ }^{32}$

\section{THE IMPERFECT POLICY WONK}

At first, it is somewhat surprising that Hale often chose not to put forward specific policy recommendations. Fried notes that: "Hale, with the exception of his work on public utilities regulation, was somewhat vague on the shape that legislative reform

\footnotetext{
${ }^{31}$ In this passage, Fried lists price discrimination as an unwanted effect of a particular regulation.

${ }^{32}$ And as discussed above, a true Lockean might want to develop a richer theory of sacrifice than the flawed "reservation price" or "threat point" approach. In describing the failings of a reservation price approach, Fried argues that:

[R]ent theory replicates the distributive embarrassments of Ramsey taxation, when (for example) it taxes the $\$ 1$ surplus value accruing to the worker paid $\$ 3 /$ hour, who (being destitute) would work for $\$ 2$ if necessary, but leaves untouched the $\$ 1,000$ an hour paid to a millionaire, who (little valuing additional money) would not work for a penny less ( $\mathrm{p} 204$ ).
}

A true Lockean might want to have government extract the surplus between the buyer's and seller's true "sacrifice" points which, as the foregoing examples suggest, might be above or below their threat points. 
should take. That omission will no doubt strike many readers as a serious limitation in his work" (p 22).

Here was a realist who was often more comfortable engaging in abstract hypotheticals concerning Esau and drowning men than focusing on concrete, salient issues of the day. But on reflection, I believe this reluctance may indicate that Hale understood where his analytic strengths lay. I find his applied policy proposals-and forays into analyzing particular constitutional issuesto be much less worthy of continued attention.

On constitutional matters, Hale at times adopted extreme positions that rendered particular constitutional clauses meaningless. For example, Hale adopted a "radical expansion of the state action doctrine," essentially deconstructing the publicprivate distinction in order to make all private acts public ( $p$ 87). The problem here is not just that Hale disregarded what Reconstruction-era legislators might have intended by drafting the Fourteenth Amendment's Equal Protection Clause to apply to states but not individuals-after all, progressives often viewed the Constitution as a "living" document. But Hale failed to provide any internal guidance as to where we should draw the line between, say, constitutionally permissible and constitutionally impermissible private acts of discrimination. An even more blatant example of his indifference to textual fidelity concerns the appropriate meaning of the Takings Clause. Hale, the progressive, argued strenuously in favor of a purely positivist view of property rights to support (among other things) the government's right to extract substantial unearned income from producers. But Hale never confronted at what point that positivist view would run afoul of the Takings Clause (pp 208-09).

Even on nonconstitutional issues, Hale's affirmative policy agenda has not aged well. For example, his preference for unreviewable agency decisionmaking is innocent of any concern with regulatory capture. He seems to have agreed with the sentiments of T.H. Green that "[t]he popular jealousy of law, once justifiable enough, is . . out of date" (p 38). ${ }^{33}$ Optimal rate regulation has moved far beyond Hale's understanding. ${ }^{34}$ It would be folly to base current policy on the details of his thinking.

\footnotetext{
${ }^{33}$ Quoting Green, Liberal Legislation at 73 (cited in note 9).

${ }^{34}$ Fried also makes the excellent observation that Hale ignored modern issues of risk in proposing cost-based rate regulation:

[P]rogressive rent theory, at least as applied to financial investments, appeared to be largely an attack on returns to risk. Hale and other proponents of a historic cost rate base for public utilities took as given the investors' right to a return equal to the normal market rate of return on investments. [But] Hale seemed to define "normal"
} 
Hale's theory of private coercion (based on government allocation of private property) did provide an important new basis for enlarging the concept of "state action." But failure to enunciate a limiting principle for either his omnipresent theory of state action or for his never-present theory of government takings severely limits the practical usefulness of his analysis. His constitutional theory and his affirmative reform proposals were substantially weaker than his more abstract criticisms of laissez faire. If not for the latter, I doubt whether Hale would have continuing interest for us today.

\section{THE FIRST LAW AND ECONOMICS MOVEMENT}

This section takes up an assertion suggested by the book's subtitle-but rarely alluded to in the text-namely, that Hale was part of "the first law and economics movement." My purpose here is not to assess the truth of the statement, but instead simply to reflect on the connections between Hale and those lawyer/economists who have followed him. I am embarrased to say that we have finally come to an issue about which I am marginally competent to comment.

Of course, Fried chose to include the reference in her title because it is provocative to think that the first law and economics movement was an "assault on laissez faire." In making this assault, Hale is certainly not a very recognizable forebearer of the Chicago school. At least with regard to his relative receptivity to government regulation, Hale's analysis is closer to more recent law and economics contributions that stress game-theoretic rationales for public market intervention. ${ }^{35}$ On the broad questions of policy, many readers will think that Hale's sympathies skipped at least a generation or two. ${ }^{36}$

Methodologically, Fried categorizes Hale as an institutionalist and a realist, but what struck me was the central role that

as the expected return on relatively riskless investments ( $p 202)$.

Hale cannot be taken to task for not having independently developed such things as the Capital Asset Pricing Model. But ignoring issues of risk would likely set prices far below investors' true reservation prices and thus undermine Hale's own stated purpose of providing adequate productivity incentives.

${ }^{*}$ See, for example, Ian Ayres, Playing Games with the Law, 42 Stan L Rev 1291 (1990), reviewing Eric Rasmussen, Games and Information: An Introduction to Game Theory (Oxford 1989); Douglas G. Baird, Robert H. Gertner, and Randall C. Picker, Game Theory and the Law (Harvard 1994).

${ }^{*}$ However, to be fair, there have been liberal law and economics practitioners from the beginning of the Chicago school. See, for example, Guido Calabresi, The Costs of Accidents: A Legal and Economic Analysis (Yale 1970) (discussing the goals of accident law and corrective justice policies such as compensation and deterrence). 
neoclassical marginalism played in Hale's thinking. I don't normally think of either realists or institutionalists of this period as focusing on the possibility that in equilibrium various marginal whatnots will tend to equal one another. On a personal level, how exciting it is for me to learn about a progressive who wasn't afraid to take a derivative. ${ }^{37}$

While Hale's normative conclusions differ sharply from the generally free market inclination of the Chicago school, Fried shows that Hale's thinking presaged several core contributions of later law and economics scholars. This is not to say (and Fried is careful not to overclaim) that Hale deserves credit for the Coase theorem or the liability/property rule distinction of Calabresi and Melamed. ${ }^{38}$ But in both of these areas, Hale's analysis foreshadowed the "theorems" that were to follow.

Like Coase, Hale understood that "any workable scheme of property rights had to accommodate conflicting uses of other property" (p 100). Fried explicitly notes this connection: "[I]n a nascent Coasian analysis that took its cue from Holmes, Hale argued that as a result of increased economic development, many of the uses of property traditionally thought to be protected now conflicted with each other" ( $p$ 101). ${ }^{39}$

Given his focus on rivalrous uses, Hale not surprisingly seized upon Miller $v$ Schoene, ${ }^{40}$ the stark property conflict between the owners of apple and cedar trees that demonstrated "the impossibility of government nonfeasance in the face of any set of conflicting rights" ( $p$ 102). Hale's approach to Miller highlights his interest in noncompatible uses, but it is still far from the Coasean insight that parties might be able to bargain around any particular rights regime to the efficient result. However, in a prosaic example about passengers taking vacant seats on a train,

\footnotetext{
${ }^{37}$ Fried's book also taught me that the Fabians (including George Bernard Shaw) were "Jevonian marginalists" ( $p$ 145).

${ }^{33}$ See Fred R. Shapiro, The Most Cited Articles from the Yale Law Journal, 100 Yale L J 1449, 1483 (1991) (quoting Guido Calabresi: "Coase's own analysis was so much more compeiling than mine, and he understood its significance so much more than I did ... that it would seem that all that was involved was the question of whether one or two people had the same insight at the same time").

${ }^{39}$ Fried also notes that "Holmes had pointed out that every tort case ... presented a problem of conflicting property or liberty interests" ( $p$ 103).

${ }^{40} 276$ US 272 (1928). In Miller, apple and cedar trees were growing on two neighboring parcels. The cedars began to harbor a fungus that endangered the apple trees. The law faced a stark either/or choice of noncompatible uses-it could allow the cedar trees to grow and sacrifice the apple trees or it could sacrifice the cedar trees to allow the apple trees to grow. The state ultimately decided to preserve the more valuable apple crop and ordered destruction of the cedar trees.
} 
Hale comes closer to recognizing how people will bargain in the shadow of different possible laws:

At the beginning of the journey there are less than a quarter as many passengers as there are seats. At that time a rule which permitted each passenger to reverse the back of the seat in front of him and occupy both seats to the exclusion of other passengers would operate equally. Any passenger excluded from the seats I occupy suffers no hardship; he can occupy two seats by himself. .. . If the early arrivals are still permitted to exclude others from the extra seats that are occupied, the latter will either have to stand up, or pay the first passengers for the privilege of occupying even one seat. And such payments, even though no greater than the value of sitting down, would not reward the recipients for any affirmative acts of service, but simply for not forcing the person who pays to stand up (pp 92-93) (emphasis added).

This passage reveals that Hale, unlike most legal scholars of his day, contemplated the ability of others to contract for rights not initially allocated. Being true to his nature, however, Hale focused instead on whether the resulting distributional effects of the law would accord with Lockean desert.

One also sees in Hale's analysis the antecedents of Calabresi and Melamed's cathedral. As Fried describes:

Hale examined . . . the effect of liability rules on market prices in involuntary exchanges. The argument is a familiar one to contemporary legal audiences, in the context of the differential effects of so-called "property" versus "liability" rules of tort damages. Anticipating that analysis in its broad outlines by several decades, Hale argued that the price at which a nonowner is allowed by law to liquidate a property interest without the consent of the owner (i.e., in an involuntary exchange) sets the outer limit on its voluntary exchange value ( $\mathrm{p} 84)$.

Protecting entitlements with liability rules had an obvious attraction for Hale because it could limit the ability of property owners to extract unreasonable prices. Esau would never have had to yield his birthright if Jacob's pottage were protected by a mere liability rule-at least against the claims of a necessitous man. Indeed, since Hale saw as "coercive" the property rule right to withhold one's property from exchange, he was inclined to sympathize with liability rules that fostered involuntary exchanges. If the liability rule damages were set at an amount 
equal to the initial owners' Lockean sacrifice (which, as noted before, progressives would imperfectly equate to the initial owners' reservation price), then liability rules could further Hale's vision of the social good.

Hale was naturally drawn to those liability rules that already existed in the law, as demonstrated by his early interest in the classic necessity case, Vincent $v$ Lake Erie Transportation Co ${ }^{41}$ In Vincent, a dock owner's property interest was ultimately protected by what we now think of as a liability rule. Hale understood the import of the ruling:

As Hale noted, ... this decision not only deprived plaintiff of the absolute right to exclude the defendant but also deprived plaintiff of the right to exact whatever defendant would have paid for the right not to be excluded. "The abrogation of the absolute power to exclude in view of the emergency abrogates likewise the power to take advantage of the shipowner's special needs, just as the power to appropriate property by eminent domain denies the owner the opportunity to take advantage of the taker's special needs" ( $p 85)^{42}$

Hale played out the implications of liability rules in a number of contexts. But, as the foregoing quotation shows, his interest seems always motivated by the distributional qualities of the rules.

Finally, I found Hale's analysis to presage one of the important insights of Michael Spence. Spence has shown that when firms incur fixed costs of producing different types of products, competitors will be led to produce the type or quality that is valued most by the marginal consumer-in an effort to induce these almost indifferent consumers to buy-and ignore the quality preferences of the inframarginal consumers. ${ }^{43}$ Hale, whose thought as a rent-theorist focused so much on the possibility of inframarginal actors, was naturally led to an analogous conclusion:

4109 Minn 456, 124 NW 221, 222 (1910). For the uninitiated, Fried notes that "[t]he defendant in Vincent had damaged plaintiff's dock after tying his boat to it during a storm without plaintiff's permission. Finding that necessity justified the defendant's mooring his boat to the dock without the owner's consent, the court nonetheless held defendant liable for the loss in value to the dock" (p 85).

${ }^{2}$ Quoting Robert L. Hale, 1 Legal Factors in Economic Society 115 (3d ed 1940) (Teaching Materials) (on file with U Chi L Rev).

4 Michael Spence, Monopoly, Quality, and Regulation, 6 Bell J Econ 417, 417 (1975). See also Ian Ayres; Supply-Side Inefficiencies in Corporate Charter Competition: Lessons from Patents, Yachting and Bluebooks, 43 U Kan L Rev 541, 560 (1995); Ian Ayres and John Braithwaite, Partial-Industry Regulation: A Monopsony Standard for Consumer Protection, 80 Cal L Rev 13, 40 (1992). 
In an unpublished manuscript written around 1915, entitled "Defects of the Marginal Utility Measure of Service," [Hale] explored the possibility that the government could increase aggregate consumer surplus over the results of the unregulated market by rechanneling resources from goods that generated low consumer surplus to inframarginal purchasers to those that could potentially generate high surplus ( $p 130$ ).

Long before Spence, Hale understood that free market forces may not drive firms to produce the assortment of product attributes that would maximize social welfare once we take into account the preferences of "inframarginal purchasers." Since most consumers are by definition inframarginal, this insight has important implications for public policy. ${ }^{44}$

\section{CONCLUSION}

Keynes long ago noted that: "Practical men, who believe themselves to be quite exempt from any intellectual influences, are usually the slaves of some defunct economist." ${ }^{\text {"45 }}$ Barbara Fried's meticulously researched book certainly shows that Halean thinking has had an unnoticed impact on certain areas of current legal thought. However, merely pointing out that Robert Lee Hale deserves more citations than he currently receives would provide a rather lackluster rationale for undertaking such painstaking labors. And Fried indeed has larger fish to fry. The book strives to point out the disturbing extent to which we are not sufficiently "slaves" to this defunct economist. Although Fried does not explicitly use Halean thought to take on modern laissez-faire

"Other aspects of Hale's thought have a strikingly modern quality. For example, in a 1931 article discussing how courts should determine market value in eminent domain cases, Hale identified the following difficulty:

The problem ... is that the market price of any piece of property depends (among other things) on the pool of potential buyers, which in turns depends in significant part on the extent of potential buyers' legal rights to circumvent the market. . . . [T]he court must implicitly decide whether to include the taker in the hypothetical market of potential buyers, and if so, whether to endow the taker with the power of eminent domain. If the taker is excluded from the hypothetical market entirely, or ... is included but given the power of taking by eminent domain at a market value determined without regard to the taker's presence in the market, the market-clearing price should reflect none of the property's idiosyncratic value to the taker (pp 84-85).

Fried's parsing of Hale seems to identify the fixed point problem that can arise when the law seeks to determine a market value which in turn is a function of the law itself. See Robert L. Hale, Value to the Taker in Condemnation Cases, 31 Colum L Rev 1 (1931).

${ }^{45}$ John Maynard Keynes, The General Theory of Employment, Interest and Money 383 (Macmillan 1936). 
extremists, this is the book's most significant contribution to contemporary debates. The widely held current belief that policymakers often need to trade off "liberty" and "equality" ignores the Halean demonstration that law cannot affect the total amount of negative liberty (it merely distributes a fixed quantum). Or, more basically, the continuing connotation that a "free" market or "laissez-faire" policy imply less governmental interference than, say, usury laws, ignores Hale's demonstration that the government's coercive force necessarily lays behind any regime of private property. Hale did not undermine the possibility that free markets could often or even normally foster the social good, but he persuasively showed that simple a priori arguments that the free market was necessarily better than redistributive regulation could not withstand scrutiny. In Hale's own words: "There may be sound reasons of economic policy to justify all the economic inequalities that flow from unequal rights. [But if so] these reasons must be more specific than a broad policy of private property and freedom of contract" ( $\mathrm{p} \mathrm{20).}{ }^{46}$. This is a lesson that bears repeating.

${ }^{46}$ Quoting Hale, 43 Colum L Rev at 628 (cited in note 13). 